\title{
UJI AKTIVITAS ANTIBAKTERI DARI ISOLAT CENDAWAN ENDOFIT ASAL TUMBUHAN SENDUDUK (Melastoma malabathricum L.) TERHADAP Escherichia coli DAN Staphylococcus aureus
}

\author{
Israwati Harahap, Vivin Paddillah Rahmi, Nofripa Herlina \\ Fakultas MIPA Dan Kesehatan Universitas Muhammadiyah Riau \\ Pekanbaru, 28293, Indonesia \\ vivinfaddillah@gmail.com
}

\section{ABSTRACT}

Endophytic fungi is a symbiotic microorganism which live inside plant tissues and not harm to their host. Several genera from endophytic fungi known to produce secondary metabolite compounds like antibiotics, anticancer, antifungal, antiviral and antimalarial. This study aimed to investigate antibacterial activity of endophytic fungi from senduduk (Melastoma malabathricum L.) against Escherichia coli and Staphylococcus aureus. Based on the test result, 11 isolates endophytic fungi from senduduk were known to have antibacterial activities. Isolate code 23 have ability to inhibit the growth of E.coli with diameters zone of inhibition is $22 \mathrm{~mm}$ and eight isolate endophytic fungi have ability to inhibit the growth of S.aureus (showed by inhibition zone).

Keyword : Antibacterial, Endophytic fungi, Melastoma malabathricum L.

\section{1}

PENDAHULUAN

Indonesia merupakan salah satu negara tropis yang memiliki keanekaragaman hayati yang cukup tinggi. Keanekaragaman hayati hutan tropika Indonesia yaitu berupa tumbuhan yang berkhasiat sebagai obat yang potensinya perlu dikaji secara sungguhsungguh untuk kepentingan kesejahteraan masyarakat. Untuk meningkatkan pengembangan budidaya dan produksi tumbuhan obat maka diperlukan berbagai usaha penelitian terhadap tumbuhan obat yang tumbuh di Indonesia (Wasitaningrum, 2009).

Salah satu penelitian terhadap tumbuhan obat yang sedang dikembangkan adalah tumbuhan obat penghasil mikroba endofit. Mikroba endofit merupakan mikroba yang hidup pada jaringan tumbuhan sebagai agen penghasil senyawa metabolit sekunder. Mikroba ini meliputi bakteri dan cendawan, yang hidup pada akar, batang maupun daun dari suatu tumbuhan. Mikroba ini mampu melindungi inangnya dengan menghasilkan senyawa metabolit sekunder yang merupakan senyawa bioaktif yang dapat membunuh patogen (Prihatiningtias, 2005). Senyawa yang dihasilkan oleh mikroba ini mirip dengan inangnya dan diduga sebagai hasil koevolusi atau transfer genetik dari inang (Tan and Zou, 2001).

Salah satu tanaman obat yang sudah dikenal dan dimanfaatkan sejak lama oleh masyarakat Indonesia adalah senduduk (Melastoma malabathricum L.) Oktavianti (2016) telah melakukan isolasi cendawan endofit dari tumbuhan senduduk. Sebanyak 26 isolat telah berhasil diisolasi dan beberapa isolat tersebut memiliki aktivitas sebagai antifungi dalam menghambat pertumbuhan Candida albicans, Sedangkan kemampuan isolat cendawan endofit tersebut dalam menghambat pertumbuhan bakteri belum diketahui. Oleh karena itu perlu dilakukan penelitian untuk menguji aktivitas antibakteri dari isolat cendawan endofit tersebut.

Bakteri uji yang digunakan yaitu Escherichia coli dan Staphylococcus aureus. E. coli dan S. aureus merupakan flora normal di saluran pencernaan tubuh manusia. Kedua bakteri ini dapat menyebabkan beberapa penyakit seperti infeksi saluran kemih, meningitis dan sepsis (Kusuma, 2009; 2010; 
Melliawati, 2009). S. aureus sering ditemukan sebagai bakteri flora normal pada kulit dan selaput lendir pada manusia, namun bakteri ini juga dapat menjadi penyebab infeksi pada manusia maupun hewan. S. aureus dapat menginfeksi jaringan atau alat tubuh lain yang menyebabkan timbulnya penyakit dengan tanda-tanda yang khas seperti nekrosis, peradangan dan pembentukan abses (Aulia, 2007).

Penyakit infeksi dapat ditangani dengan menggunakan antibiotik. Terapi antibiotik beberapa tahun lalu dinyatakan berhasil dalam mengatasi penyebaran mikroba patogen. Akan tetapi, maraknya penggunaan antibiotik yang tidak tepat dapat menyebabkan resistensi terhadap mikroba patogen (Sjahrurrahman et al., 1999). Hal ini mendorong untuk dilakukannya pencarian antibiotik (senyawa bioaktif) yang baru yaitu salah satunya dengan memanfaatkan senyawa bioaktif dari cendawan endofit asal tumbuhan senduduk $(M$. malabathricum L.).

\section{METODE PENELITIAN}

a. Waktu dan Tempat Penelitian

Penelitian dilaksanakan pada bulan April sampai Juni 2017 di Laboratorium Mikrobiologi Fakultas MIPA dan Kesehatan, Universitas Muhammadiyah Riau dan di Laboratorium Biokimia, FMIPA, Universitas Riau.

\section{b. Alat dan Bahan}

Alat yang digunakan dalam penelitian ini adalah oven (Memmert), autoklaf, (All American), kompor listrik (Maspion), cawan petri (Pyrex), rak tabung reaksi, tabung reaksi, gunting, erlenmeyer, pipet tetes, tissue, alumunium foil, kapas, beaker glass (Pyrex), kertas label, bunsen, plastik, kertas, glass object, jarum ose, cling wrep, laminar air flow (LAF), timbangan analitik (Radweg), dan cotton swab.

Bahan yang digunakan dalam penelitian ini adalah 26 isolat cendawan endofit asal tumbuhan senduduk (M. malabathricum L.), biakan E. coli dan S. aureus, Potato Dextrose Agar (PDA), Potato Dextrose Broth (PDB), Nutrient Agar (NA) dan Nutrient Broth (NB).

\section{c. Prosedur Penelitian}

\section{Peremajaan Isolat}

Peremajaan isolat cendawan endofit dilakukan dengan menumbuhkan kembali isolat-isolat cendawan endofit yang telah murni ke dalam media PDA dan diinkubasi selama 57 hari pada suhu $25^{\circ} \mathrm{C}$.

\section{Produksi Senyawa Metabolit Sekunder dari Isolat}

Koloni cendawan endofit yang telah diinkubasi pada media PDA selama 5-7 hari pada suhu $25^{\circ} \mathrm{C}$, diambil satu ose dan diinokulasi ke dalam tabung reaksi yang berisi $10 \mathrm{ml}$ media PDB kemudian diinkubasi pada suhu $25^{\circ} \mathrm{C}$ menggunakan shaker inkubator selama 21 hari.

\section{Persiapan Bakteri Uji}

Kultur murni E. coli dan S. aureus diambil dengan menggunakan jarum ose dan diinokulasi ke dalam tabung reaksi yang telah berisi $10 \mathrm{ml}$ NB. Selanjutnya diinkubasi selama 18-24 jam pada suhu ruang.

\section{Uji Aktivitas Antibakteri}

Pengujian aktivitas antibakteri dilakukan dengan metode sumuran. Bakteri uji yang telah berumur 24 jam diambil dengan cotton swab. Selanjutnya cotton swab dicelupkan ke dalam tabung reaksi dan ditekan perlahan pada dinding tabung reaksi agar cotton swab tidak terlalu basah, kemudian diusap secara horizontal pada media NA. Media NA dilubangi dengan menggunakan sedotan kecil berdiameter $6 \mathrm{~mm}$. Setiap cawan petri terdiri dari 3 sumuran yang berisi senyawa metabolit sekunder hasil fermentasi isolat cendawan endofit. Selanjutnya diinkubasi pada suhu ruang dan diamati zona hambat yang terbentuk selama 24-48 jam. Zona hambat yaitu zona bening yang terbentuk di sekitar sumuran. Zona hambat yang terbentuk disekitar sumuran selanjutnya diukur diameternya. Diameter zona hambat diperoleh dengan cara mengukur selisih diameter zona hambat $(\mathrm{mm})$ dengan diameter sumuran (Azzoro, 2002). 


\section{HASIL DAN PEMBAHASAN}

\section{a. Peremajaan Isolat}

Peremajaan isolat cendawan endofit dilakukan dengan menumbuhkan kembali isolat-isolat cendawan endofit yang telah murni ke dalam media PDA dan diinkubasi selama 5-7 hari pada suhu $25^{\circ} \mathrm{C}$. Sebanyak 11 isolat cendawan endofit berhasil diremajakan dan digunakan untuk uji aktivitas antibakteri. Setelah dilakukan peremajaan isolat cendawan endofit, maka dilanjutkan dengan proses fermentasi untuk memperoleh ekstrak yang mengandung senyawa metabolit sekunder dari isolat cendawan endofit. Fermentasi cendawan endofit dilakukan dengan cara menumbuhkannya di dalam media PDB. Proses fermentasi cendawan endofit digunakan media PDB karena fermentasi dengan media cair lebih efektif untuk memproduksi biomassa (Pokhrel dan Ohga, 2007) dan senyawa bioaktif dibandingkan fermentasi dalam media padat. Hal ini karena dalam fermentasi cair terdapat proses agitasi yang memungkinkan nutrisi dalam media dapat terus homogen dan tidak ada gradien kosentrasi produk/toksin, sehingga dapat lebih optimal mengabsorbsi nutrisi tersebut (Yan et al., 2015).

\section{b. Uji Aktivitas Antibakteri}

Pengujian senyawa antibakteri dilakukan terhadap dua bakteri target yang mewakili kelompok bakteri Gram positif dan Gram negatif. Menurut Prescott, et al. (2002), adanya penghambatan isolat cendawan endofit terhadap pertumbuhan mikroba target, terlihat dari terbentuknya zona hambatan di sekeliling koloni isolat cendawan endofit. Sebelas isolat yang berhasil diremajakan, 9 isolat memiliki aktivitas dalam menghambat $E$. coli yaitu, isolat $8,14,16,18,19,21,22,23,25$ dan 10 isolat memiliki aktivitas dalam mengambat $S$. aureus yaitu isolat $3,10,14,16,18,19,21,22$,
23, 25. Zona hambat yang dihasilkan oleh isolat cendawan endofit menunjukkan adanya aktivitas antibakteri (Tabel 1)

Tabel 1. Uji Aktivitas Antibakteri dari Isolat Cendawan Endofit Asal Tumbuhan Senduduk (M. malabathricum L. ) Terhadap E. coli dan S. aureus

\begin{tabular}{|c|c|c|c|}
\hline \multirow[b]{2}{*}{ No. } & \multirow[b]{2}{*}{ Isolat } & \multicolumn{2}{|c|}{ E. coli } \\
\hline & & $\begin{array}{c}\text { Zona } \\
\text { Hambat } \\
(\mathrm{mm})\end{array}$ & Kategori \\
\hline 1 & Isolat 3 & - & - \\
\hline 2 & Isolat 8 & 9 & Medium \\
\hline 3 & $\begin{array}{c}\text { Isolat } \\
10\end{array}$ & & - \\
\hline 4 & $\begin{array}{c}\text { Isolat } \\
14\end{array}$ & 14 & Kuat \\
\hline 5 & $\begin{array}{c}\text { Isolat } \\
16\end{array}$ & & Kuat \\
\hline 6 & Isolat & 19 & Kuat \\
\hline 7 & $\begin{array}{c}18 \\
\text { Isolat }\end{array}$ & 18 & Kuat \\
\hline & 19 & & \\
\hline 8 & $\begin{array}{c}\text { Isolat } \\
21\end{array}$ & 13 & Kuat \\
\hline 9 & $\begin{array}{c}\text { Isolat } \\
22\end{array}$ & 5 & Medium \\
\hline 10 & $\begin{array}{c}\text { Isolat } \\
23\end{array}$ & 22 & Sangat Kuat \\
\hline 11 & $\begin{array}{c}\text { Isolat } \\
25 \\
\end{array}$ & 13 & Kuat \\
\hline & & & eus \\
\hline No. & Isolat & $\begin{array}{c}\text { Zona } \\
\text { Hambat } \\
(\mathbf{m m})\end{array}$ & Kategori \\
\hline 1 & Isolat 3 & 6 & Medium \\
\hline 2 & Isolat 8 & - & - \\
\hline 3 & $\begin{array}{c}\text { Isolat } \\
10\end{array}$ & 20 & Kuat \\
\hline 4 & $\begin{array}{c}\text { Isolat } \\
14\end{array}$ & 4 & Lemah \\
\hline 5 & $\begin{array}{c}\text { Isolat } \\
16\end{array}$ & 19 & Kuat \\
\hline 6 & $\begin{array}{c}\text { Isolat } \\
18\end{array}$ & 14 & Kuat \\
\hline 7 & $\begin{array}{c}\text { Isolat } \\
19\end{array}$ & 12 & Kuat \\
\hline 8 & $\begin{array}{c}\text { Isolat } \\
21\end{array}$ & 19 & Kuat \\
\hline
\end{tabular}




\begin{tabular}{cccc}
9 & $\begin{array}{c}\text { Isolat } \\
22\end{array}$ & 19 & Kuat \\
10 & $\begin{array}{c}\text { Isolat } \\
23\end{array}$ & 12 & Kuat \\
11 & $\begin{array}{c}\text { Isolat } \\
25\end{array}$ & 18 & Kuat \\
& & \\
\hline
\end{tabular}

Keterangan: - (tidak ada zona hambat)

Tabel 1 menunjukan bahwa 11 isolat yang di uji kemampuan antibakterinya terhadap $E$. coli, 1 isolat termasuk ke dalam kategori sangat kuat, 6 isolat termasuk ke dalam kategori kuat, 2 isolat termasuk ke dalam kategori medium dan 2 isolat tidak menunjukkan aktivitas antibakteri. Sedangkan kemampuan isolat cendawan endofit dalam menghambat pertumbuhan bakteri $S$. aureus menunjukkan 8 isolat termasuk ke dalam kategori kuat, 1 isolat termasuk ke dalam kategori medium, 1 isolat termasuk ke dalam kategori lemah dan 1 isolat tidak menunjukkan aktivitas antibakteri. Ketentuan daerah hambatan adalah sebagai berikut: daerah hambatan $>20 \mathrm{~mm}$ tergolong kategori sangat kuat, daerah hambatan 10-20 $\mathrm{mm}$ tergolong kuat, 5-9 $\mathrm{mm}$ tergolong sedang dan daerah hambatan $<5 \mathrm{~mm}$ tergolong kategori lemah (Davis, 1971).

Menurut Hasim (2003), kekuatan antibiotik dapat ditentukan sebagai berikut: daerah hambatan $20 \mathrm{~mm}$ atau lebih mempunyai potensi antibiotik "sangat kuat", daerah hambatan $10 \mathrm{~mm}-20 \mathrm{~mm}$ mempunyai potensi antibiotik "kuat", daerah hambatan 5$10 \mathrm{~mm}$ mempunyai potensi antibiotik "sedang" dan daerah hambatan $5 \mathrm{~mm}$ atau kurang mempunyai potensi antibiotik "lemah".

Berdasarkan hasil pengamatan, isolat 23 menghasilkan zona hambat terbesar terhadap E. coli dengan diameter $22 \mathrm{~mm}$ dan isolat 10 menghasilkan zona hambat terbesar terhadap S. Aureus dengan diameter $20 \mathrm{~mm}$ (Gambar 1).

a.)

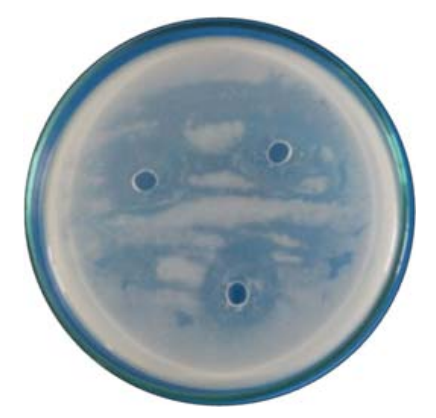

b.)

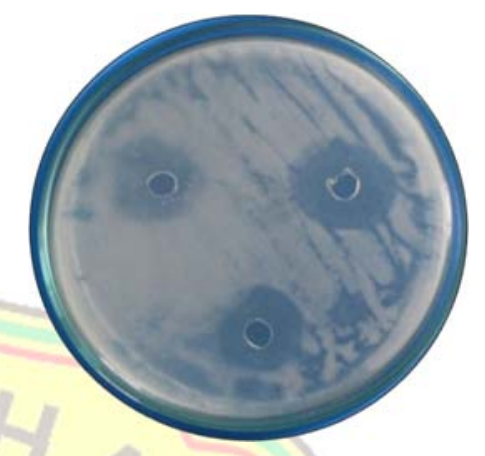

Gambar 1. Uji Aktivitas antibakteri pada media NA. (a) Isolat 23 terhadap E. Coli (b) isolat 10 terhadap S. aureus

Gambar 1 menunjukkan bahwa zona hambat terbesar dihasilkan oleh isolat 23 dengan diameter sebesar $22 \mathrm{~mm}$ terhadap $E$. coli, sedangkan isolat 10 dengan diameter sebesar $20 \mathrm{~mm}$ terhadap bakteri uji S. aureus. Zona hambat terkecil dihasilkan oleh isolat 22 dengan diameter sebesar $5 \mathrm{~mm}$ yang di uji pada E. coli, dan isolat 14 dengan diameter sebesar $4 \mathrm{~mm}$ yang di uji pada $S$. aureus. Terbentuknya zona hambat di sekitar sumuran menandakan bahwa isolat cendawan endofit tersebut diduga mengandung antibiotik. Antibiotik adalah zat yang dihasilkan oleh suatu mikroba, terutama fungi, yang dapat menghambat atau membasmi mikroba jenis lain (Setiabudi, 2007).

Aktivitas antibakteri dapat diketahui dengan melihat ada atau tidaknya daerah hambatan (zona hambat) pada pertumbuhan bakteri di media padat. Hasil penelitian menunjukkan bahwa sebagian besar isolat cendawan endofit asal tumbuhan senduduk memiliki aktivitas antibakteri yang kuat. Hal ini ditunjukkan dengan pembentukan daerah hambat dengan diameter yang cukup besar, baik pada koloni E. coli maupun $S$. aureus (Tabel 1).

Zona hambat yang dihasilkan oleh cendawan endofit tersebut menunjukkan 
bahwa isolat mampu menghasilkan metabolit sekunder sebagai antibakteri. Hal ini sesui dengan pernyataan Prihatiningtias, (2005) bahwa kemampuan isolat cendawan endofit menghambat pertumbuhan bakteri karena isolat cendawan endofit mengandung senyawa metabolit sekunder yang merupakan senyawa bioaktif yang dapat membunuh patogen.

Berdasarkan hasil pengukuran diameter zona hambatan terlihat bahwa kemampuan isolat cendawan endofit lebih besar dalam menghambat pertumbuhan $E$ coli dibandingkan dengan $S$. aureus. Hal ini disebabkan karena komponen dari dinding sel kedua bakteri uji berbeda. E.coli merupakan bakteri Gram negatif, dinding sel terdiri atas satu lapis atau lebih peptidoglikan yang tipis, sehingga sensitif terhadap senyawa antimikroba, dibandingkan dengan $S$. aureus yang merupakan bakteri Gram positif yang terdiri atas beberapa lapisan peptidoglikan yang membentuk struktur yang tebal (Radji, 2011).

Perbedaan diameter zona hambat juga disebabkan oleh beberapa faktor diantaranya kecepatan difusi, ukuran molekul dan stabilitas bahan antibakteri, sifat media yang digunakan, jumlah organisme yang diinokulasi, kecepatan tumbuh bakteri, konsentrasi bahan kimia serta kondisi pada saat inkubasi (Munifatul, 2007).

\section{KESIMPULAN}

Sebanyak 11 isolat cendawan endofit asal senduduk memiliki kemampuan dalam menghambat pertumbuhan bakteri. Zona hambat terbesar dihasilkan oleh isolat 23 dalam menghambat pertumbuhan $E$. coli sebesar $22 \mathrm{~mm}$ dan 8 isolat berpotensi dalam menghambat pertumbuhan $S$. aureus.

\section{DAFTAR PUSTAKA}

Aulia A, Thihana \& Mirhanuddin. 2007. Potensi ekstrak kayu ulin (eusideroxylon zwageri $\mathrm{T}$ et $\mathrm{B}$ ) dalam menghambat pertumbuhan bakteri Staphylococcus aureus secara in vitro. Bioscientiae. 4(1):37-42.
Azzoro, C. 2002. Antibacterial Activity of Crude Extract of Azadirachta indica on Salmonella typhi. World J. Biotecnol. 3:354-357.

Davis, W.W., dan T. R. Stout. 1971. Disc Plate Method of Microbiological Antibiotic Assay. Applied Microbiology. 22: 659 -665 .

Hasim. 2003. Menanam Rumput, Memanen Antibiotik. Jakarta: Kompas No. 127. Tahun ke-39.

Kusuma S. A. F. 2009. Staphylococcus aureus. [Makalah]. Jatinangor: Fakultas Farmasi Universitas Padjadjaran.

Melliawati, R. 2009. Escherichia coli dalam Kehidupan Manusia. BioTrends. 4:10.

Munifatul, I. 2007. Skreening Potensi Antibakteri pada Beberapa Spesies Rumput Laut terhadap Bakteri Patogen pada Udang Windu. Jurnal BIOMA. 9(2): 62-67. ISSN 1410-8801.

Octavianti, Rusi. 2016. Isolasi Cendawan Endofit dari Tumbuhan Senduduk (Melastoma malabathricum L.) dan Potensinya Sebagai Antifungi. [Skripsi]. Pekanbaru: Universitas Muhammadiyah Riau.

Pokhrel, C.P \& Ohga, S. 2007. Submerged Culture Conditions for Mycelial Yield and Polysaccharides Production by Lyophyllum decastes. Food Chemistry, $105,641-646$.

Prescott, L. M., J. P. Harley, and D. A. Klein. 2002. Microbiology 5 th ed. USA: Mc Graw-Hill.

Prihatiningtias, W. 2005. Senyawa Bioaktif Fungi Endofit Akar kuning (Fibraurea chloroleuca Miers) Sebagai Senyawa Antimikroba. [Tesis]. Yogyakarta: Sekolah Pascasarjana. Universitas Gajah Mada. Radji, M.. 2011. Buku Ajar Mikrobiologi, Panduan Mahasiswa Farmasi dan Kedokteran, 50. Jakarta, EGC. 
Setiabudi, R. 2007. Farmakologi dan Terapi. Edisi 5. Departemen Farmakologi dan Terapeutik FKUI. Jakarta: Balai Penerbit FKUI.

Tan, R. X. \& Zou, W. X. 2001. Endophytes: a Rich Source of Functional Metabolites. Nat Prod Rep. 18:448-459.

Sjahrurachman A, W. Kumala \& T. Nurjadi. 1999. Kepekaan Kuman Terhadap Antibiotika Golongan Kuinolon dan Sefalosporin. CDK 124. p. 17-20.

Wasitaningrum. 2009. Uji Resistensi bakteri Staphylococcus aureus terhadap beberapa Antibiotik. Surakarta: UMS

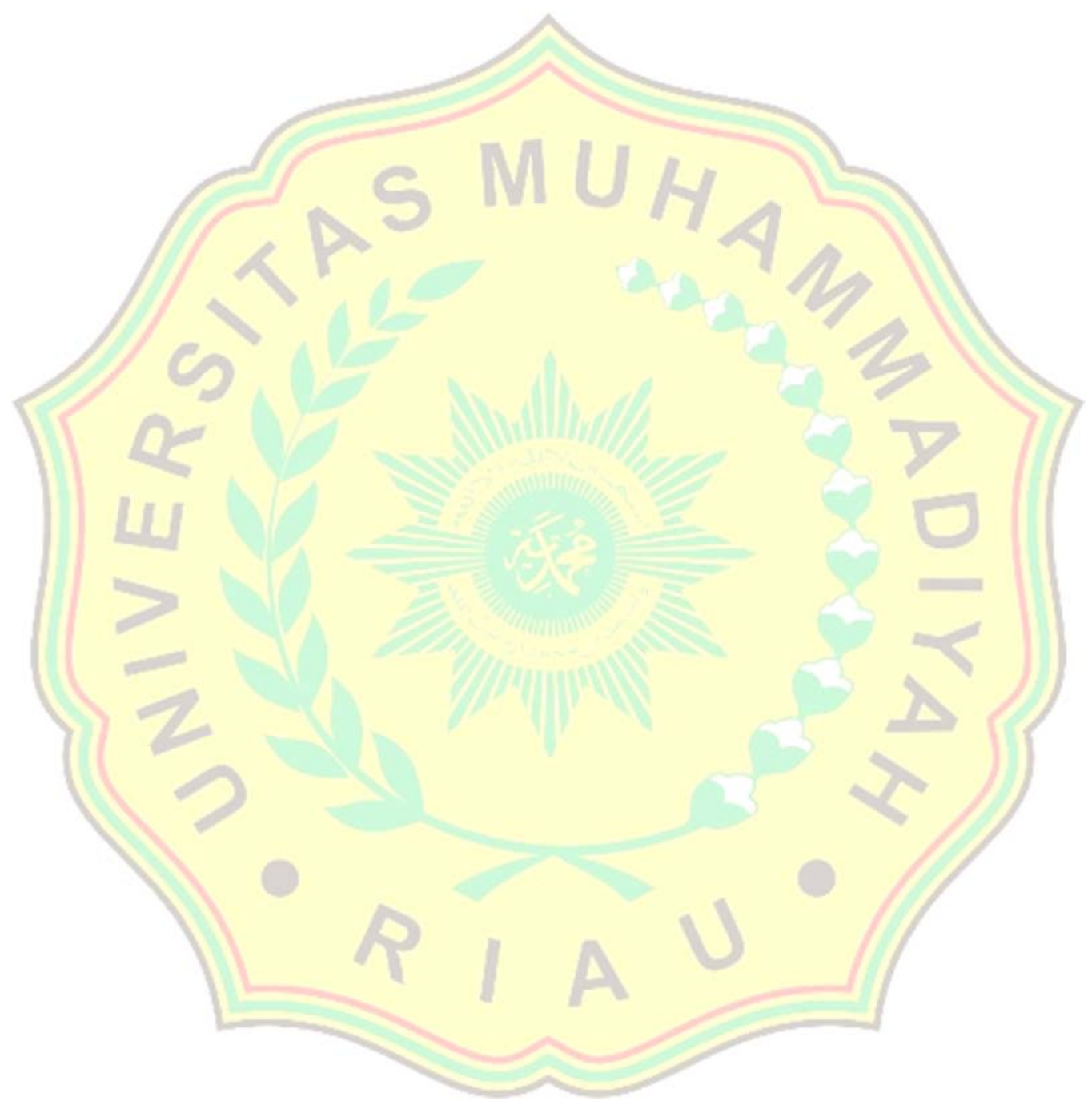

